\title{
Efficacy of different botanical and synthetic insecticides on red pumpkin beetle (Aulacophora foveicollis) in bitter gourd
}

Iftikhar Ahmed ${ }^{1}$, Sher Ahmed ${ }^{2 *}$, Abdul Hanan ${ }^{2}$, Kamran Jamil $^{1}$, Muhammad Iqbal Jakhro ${ }^{2}$, Abdul Latif ${ }^{2}$, Muhammad Akbar Badini ${ }^{3}$, Nazeer Ahmed ${ }^{4}$, Zahoor Ahmed khetran ${ }^{5}$ and Shahzad Ahmed Shahwani ${ }^{2}$

1. Department of Agriculture Extension, Rani Bagh Sariab Road, Quetta-Pakistan

2. PARC-Balochistan Agricultural Research and Development Centre Western Bypass Brewery Road, Quetta-

Pakistan

3. Directorate of Post-Harvest, Agriculture Research Institute Sariab Road, Quetta-Pakistan

4. PARC-ARI Turbat BARDC, Balochistan-Pakistan

5. PARC-ARI Jaffarabad BARDC, Balochistan-Pakistan

*Corresponding author's email: sherbardc@gmail.com

Citation

Iftikhar Ahmed2, Sher Ahmed, Abdul Hanan, Kamran Jamil, Muhammad Iqbal Jakhro, Abdul Latif, Muhammad Akbar Badini, Nazeer Ahmed, Zahoor Ahmed khetran and Shahzad Ahmed Shahwani. Efficacy of different botanical and synthetic insecticides on red pumpkin beetle (Aulacophora foveicollis) in bitter gourd. Pure and Applied Biology. Vol. 8, Issue 1, pp530-536. http://dx.doi.org/10.19045/bspab.2018.700213

\begin{tabular}{llll}
\hline \hline Received: 08/10/2018 & Revised: 05/12/2018 & Accepted: 07/12/2018 & Online First: 14/12/2018 \\
\hline
\end{tabular}

\section{Abstract}

Present experiment was laid out to study the efficacy of different botanicals and synthetic insecticides against red pumpkin beetle in bitter gourd crop. The trail was conducted at Research Farm of Bakhra Shaker Khan, Sibi-Balochistan. Five Treatments viz., Neem oil 1L/acre, Castor oil 1L/acre, Melathion 250L/acre, Imidachloprid 250L/acre with a control (untreated) plot was utilized for this experiment. The efficacy of insecticides was obs8erved after 0, 24, 72 and 7 days of insecticides spraying. 2.94, 2.92, 3.22, 3.72 and 4.17 larvae / leaf was died against Neem oil after 0 hrs, $24 \mathrm{hrs}, 48 \mathrm{hrs}, 72 \mathrm{hrs}$ and 7 days, similarly 3.22, 3.31, 3.81, 4.08 and 4.31 after 0 hrs, $24 \mathrm{hrs}, 48 \mathrm{hrs}, 72 \mathrm{hrs}$ and 7 days against Caster oil, 2.09, 1.32, 1.34, 2.17 and 3.15 after 0 hrs, 24 hrs, $48 \mathrm{hrs}, 72 \mathrm{hrs}$ and 7 days against Melathanion, 1.93, 1.98, 2.09, 2.29 and 31 after 0 hrs, 24 hrs, 48 hrs, 72 hrs and 7 days against Imidachloprid. In control 3.407, 3.95, 4.00, 4.42 and 5.64 after $0 \mathrm{hrs}, 24 \mathrm{hrs}, 48 \mathrm{hrs}, 72 \mathrm{hrs}$ and 7 days was noted. The results indicated that Melathion 250 / acre and Imidachloprid 250L/acre are highly effective against Aulacophora foveicollis.

Keywords: Bitter Gourd; Efficacy; Plant extract; Red pumpkin beetle; Synthetic insecticides

Introduction

Bitter gourd (Momordica charantia L.) is a Cucurbitaceous family and cross-pollinated crop. It is used as a vegetable widespread grown-up and rest of the world [1]. It is also cultivated as an important vegetable crop in 
many areas of Pakistan [2]. [3] Studied that the fruit fly (Bactrocera cucurbitae), and Red Pumpkin beetle (Aulacophora foveicollis) are dangerous insect pests of bitter gourd plant. Red Pumpkin Beetle (Aulacophora foveicollis) as a serious insect pest of cucurbitaceous vegetables, cucumber, melons and it is an important crop of Pakistan; it heavy losses due to the pest Red pumpkin beetle. By the application of chemical pesticides pumpkin beetle is mostly controlled. Yield is usually losses 30-100\% due to red pumpkin beetle [4]. Losses due to infestation are quite evident which may reach up to $35-75 \%$ [5]. The pest is occurring throughout the year which causes serious damage to the crops [6]. Some studies have already been done on the different factors relating to the abundance of red pumkin beetle in different crops [7-9]. The most commonly used method for controlling red pumpkin beetle in Bangladesh is the application of insecticides [10]. But the main problem is indiscriminate application of the doses of synthetic pesticides. However, due to the unconscious use of synthetic insecticide development of insect resistance to insecticides, induction of resurgence to target pests, outbreak of secondary pests and undesirable effect on non-target organisms as well as serious environment pollutions is occurred. Insecticide residues can exist in fruit which cause health hazard to consumers. To control this pest properly it is necessary to determine the extent of damage and to find out the accurate dose of the insecticide. Keeping in view the above facts and figures this study was conducted to equate the efficacy of different insecticides / botanicals against Red Pumpkin beetle (Aulacophora foveicollis) in Bitter gourd.

\section{Materials and methods}

To check the efficacy of different botanical and synthetic insecticides on red pumpkin beetle in better gourd. The research trail was conducted at Research Farm of Bakhra
Shaker Khan, Sibi - Balochistan. The detail of experiment is given below:

\section{Experiment Design}

Experimental design was conducted in Randomized Complete Bloch Design with 3 replication and the details of treatments is given bellow.

$\mathrm{T}_{1}$ Neem

$\mathrm{T}_{2}$ Castor.

$\mathrm{T}_{3}$ Melathion

$\mathrm{T}_{4}$ Imidachloprid

T5 control

Uniform cultural practices were applied to all the treatments. Selected ten plants to record the pest infestation. Pre and post observations were recorded, pre-treatment observation was taken before 24 hours. And post was recorded after 24, 48, 72 hours and 1 week after treatments application.

\section{Statistical analysis}

Using computer software program Statistix 8.1 [11] by two ways ANOVA was conducted, and Tukey HSD at $\mathrm{p}$ value 0.05 was applied for comparison of means.

\section{Results and discussion}

To check the efficacy of different botanicals and synthetic insecticides on red pumpkin beetle (Aulacophora foveicollis) in Bitter gourd the research was conducted at Research Farm of Bakhra Shaker Khan Tehsil, District Sibi Balochistan province. where the red pumpkin beetle attack as a key pest on bitter gourd, Cucumber and pumpkin. The following Botanicals and synthetic insecticides such asT1 $=$ Neem Oil 1L/acre, $\mathrm{T} 2=$ Castor Oil 1L/acre, T3= Malathion 250L/acre, T4= Imidacloprid 250L/acre and T5 = Control were sprayed three times on the crop. The observations were recorded on population of red pumpkin beetle pre and post spraying.

Effect of various botanicals and synthetic insecticides on red pumpkin beetle (Aulacophora foveicollis) in Bitter gourd before and after $1^{\text {st }}$ Spray 
The data in (Table 1) revealed that pretreatment count of red pumpkin beetle was $22.75,21.25,21,75,20.75$ and 14.00adults /plot of bitter gourd in T1, T2, T3, T4 and T5. After first spray, average mortality of red pumpkin beetle was counted as $32.59 \%, 46.26 \%, 56.92 \%$ and $53.36 \%$ on $\mathrm{T} 1,22.79 \%, 36.90 \%, 47.29 \%$ and $38.97 \%$ on $\mathrm{T} 2,39.65 \%, 67.36 \%, 83.90$ and $68.83 \%$ on $\mathrm{T} 3,28.31 \%, 54.38 \%, 69.63 \%$ and $57.38 \%$ on
T4 after 24 hrs, 48 hrs, 72 and one week, respectively. An average mortality of red pumpkin beetle on first spray $32.59 \%$, $22.79 \%, 39.65 \%$, and $28.31 \%$, for T1, T2, T3 and T4 were recorded, respectively. Maximum efficacy of different botanicals and synthetic insecticides on red pumpkin beetle on bitter gourd after $1^{\text {st }}$ spray was examined for T3 $(83.90 \%)$ followed by T4 (69.63\%), T1 (56.92\%), and T2 (47.29\%).

Table 1. Effect of various botanicals and synthetic insecticides on red pumpkin beetle (Aulacophora foveicollis) in Bitter gourd before and after $1^{\text {st }}$ spray

\begin{tabular}{|c|c|c|c|c|c|c|}
\hline \multirow[t]{2}{*}{ Treatments } & \multirow{2}{*}{$\begin{array}{c}\text { Pre- } \\
\text { treatment }\end{array}$} & \multicolumn{4}{|c|}{ Post-treatment } & \multirow{2}{*}{$\begin{array}{c}\text { Maximum efficacy } \\
\%\end{array}$} \\
\hline & & $24 \mathrm{hrs}$ & $48 \mathrm{hrs}$ & 72 hrs & 1 week & \\
\hline $\mathbf{T 1}$ & 22.75 & $\begin{array}{c}17.50 \\
(32.59)\end{array}$ & $\begin{array}{c}15.50 \\
(46.26)\end{array}$ & $\begin{array}{c}14.00 \\
(56.92)\end{array}$ & $\begin{array}{c}18.00 \\
(53.36)\end{array}$ & 56.92 \\
\hline $\mathbf{T} 2$ & 21.25 & $\begin{array}{c}18.75 \\
(22.79)\end{array}$ & $\begin{array}{c}17.00 \\
(36.90)\end{array}$ & $\begin{array}{c}16.00 \\
(47.29)\end{array}$ & $\begin{array}{c}22.00 \\
(38.97)\end{array}$ & 47.29 \\
\hline T3 & 21.75 & $\begin{array}{c}15.00 \\
(39.65)\end{array}$ & $\begin{array}{c}9.00 \\
(67.36)\end{array}$ & $\begin{array}{c}5.00 \\
(83.90)\end{array}$ & $\begin{array}{c}11.50 \\
(68.83)\end{array}$ & 83.90 \\
\hline T4 & 20.75 & $\begin{array}{l}17.00 \\
(28.31)\end{array}$ & $\begin{array}{c}12.00 \\
(54.38)\end{array}$ & $\begin{array}{c}9.00 \\
(69.63)\end{array}$ & $\begin{array}{c}15.00 \\
(57.38)\end{array}$ & 69.63 \\
\hline T5 & 14.00 & 16.00 & 17.75 & 20.00 & 23.75 & \\
\hline $\begin{array}{ll}\text { S.E } \pm & =1.41 \\
\text { LSD 0.05 } & =2.81 \\
\text { F-Value } & =7.45 \\
\text { P-Value } & =0.00 \\
\text { CV\% } & =27.3\end{array}$ & & & & & & \\
\hline
\end{tabular}

Effect of various botanicals and synthetic insecticides on red pumpkin beetle on bitter gourd before and after $2^{\text {nd }}$ spray

It was observed that in (Table 2) data showed that pre-treatment count of red pumpkin beetle 26.00, 28.25, 27.50, 30.00 and 17.00adults /plot of bitter gourd were determined for $\mathrm{T} 1, \mathrm{~T} 2, \mathrm{~T} 3, \mathrm{~T} 4$ and $\mathrm{T} 5$. In post-treatment data, average mortality of red pumpkin beetle was recorded as $20.85 \%$, $42.88 \%, 59.55 \%$ and $48.09 \%$ on $\mathrm{T} 1,17.65 \%$, $41.89 \%, 55.33 \%$ and $44.87 \%$ on $\mathrm{T} 2,44.68 \%$, $68.73 \%, 89.80$ and $71.21 \%$ on $\mathrm{T} 3,40.35 \%$, $63.52 \%, 80.72 \%$ and $65.82 \%$ against t 4 post 241 hours, 481 hours, $721 \&$ one 7 days.
Averagely date rate of red pumpkin beetle in $2^{\text {nd }}$ spray $20.85 \%, 17.65 \%, 44.68 \%$, and $40.35 \%$, for $\mathrm{t} 1, \mathrm{t} 2, \mathrm{t} 3 \& \mathrm{t} 4$ were recorded. Highly effect of different botanicals \& pesticides on red pumpkin beetle on bitter gourd after $2^{\text {nd }}$ spray was recorded for $\mathrm{t} 3$ $(89.80 \%)$ with t4 (80.72\%), T1 (59.55\%), and T2 $(55.33 \%)$.

\section{Overall average efficacy}

The average effect of various botanicals and synthetic insecticides against red pumpkin beetle (Aulacophora foveicollis) on Bitter gourd for two sprays was worked out and thus data (Table 3) indicated that among the insecticide, the highest average efficacy 
$(86.85 \%)$ was observed in case of T3 against red pumpkin beetle (Aulacophora foveicollis) population followed by $75.17,51.31$ and 51.23 for T4, T2 and T1, respectively.

Table 2. Effect of various botanicals and synthetic insecticides on red pumpkin beetle (Aulacophora foveicollis) on Bitter gourd before and after second spray

\begin{tabular}{|c|c|c|c|c|c|c|}
\hline \multirow[t]{2}{*}{ Treatments } & \multirow{2}{*}{$\begin{array}{l}\text { Pre- } \\
\text { treatment }\end{array}$} & \multicolumn{4}{|c|}{ Post-treatment } & \multirow{2}{*}{$\begin{array}{l}\text { Maximum efficacy } \\
\%\end{array}$} \\
\hline & & 24 hrs & 48 hrs & 72 hrs & 1 week & \\
\hline T1 & 26.00 & $\begin{array}{l}23.00 \\
(20.85)\end{array}$ & $\begin{array}{l}19.00 \\
(42.88)\end{array}$ & $\begin{array}{l}15.00 \\
(59.55)\end{array}$ & $\begin{array}{l}26.00 \\
(48.09)\end{array}$ & 59.55 \\
\hline T2 & 28.25 & $\begin{array}{l}26.00 \\
(17.65) \\
\end{array}$ & $\begin{array}{l}21.00 \\
(41.89) \\
\end{array}$ & $\begin{array}{l}18.00 \\
(55.33) \\
\end{array}$ & $\begin{array}{l}30.00 \\
(44.87)\end{array}$ & 55.33 \\
\hline T3 & 27.50 & $\begin{array}{l}17.00 \\
(44.68) \\
\end{array}$ & $\begin{array}{l}11.00 \\
(68.73) \\
\end{array}$ & $\begin{array}{l}4.00 \\
(89.80) \\
\end{array}$ & $\begin{array}{l}15.25 \\
(71.21)\end{array}$ & 89.80 \\
\hline T4 & 30.00 & $\begin{array}{l}20.00 \\
(40.35)\end{array}$ & $\begin{array}{l}14.00 \\
(63.52)\end{array}$ & $\begin{array}{l}8.25 \\
(80.72)\end{array}$ & $\begin{array}{l}19.75 \\
(65.82)\end{array}$ & 80.72 \\
\hline T5 & 17.00 & 19.00 & 21.75 & 24.25 & 32.75 & \\
\hline
\end{tabular}

$\begin{array}{ll}\text { S.E } \pm & =1.9444 \\ \text { LSD 0.05 } & =3.8616 \\ \text { F-Value } & =6.90 \\ \text { P-Value } & =0.0001 \\ \text { CV\% } & =29.20 \%\end{array}$

Table 3. Overall average efficacy of insecticide against red pumpkin beetle (Aulacophora foveicollis) on Bitter gourd

\begin{tabular}{|c|c|c|c|}
\hline Plant extracts & First spray & Second spray & Average \\
\hline T1 & 56.92 & 59.55 & 51.23 \\
\hline T2 & 47.29 & 55.33 & 51.31 \\
\hline T3 & 83.90 & 89.80 & 86.85 \\
\hline T4 & 69.63 & 80.72 & 75.17 \\
\hline
\end{tabular}

Red Pumpkin beetle is a key pest of bitter gourd and it has been reported as a destructive insect pest of cucurbitaceous vegetables, cucumber and melons. Red Pumpkin beetle is injurious to the crops in both larval and adult stages. Red pumpkin beetle is one of the most serious insect pests of cucurbit which losses 30-100\% yield [12]. In this study it was observed that Melathion 250L/acre was recorded very effective against red pumpkin beetle followed by Imidachloprid. 250L/acre, neem oil 1L/acre and castor oil 1L/acre after first and second spray. In third spray results were quite different, results of third spray showed that Imidachloprid was recorded most effective as compare to Melathion followed by castor and neem oil. Our results were more resembled with the results of [13] recommended different controlling measures against red pumpkin beetle which includes endrin $0.02 \%$ or Melathion $0.1 \%$ at $1000 \mathrm{~L} / \mathrm{ha}$ or $5 \%$ dust of Melathion at $2 \mathrm{~kg} / \mathrm{ha}$. Furthermore [14] observed some plant products against red pumpkin beetle out of which Garomin (49.89) and Neem leaf extracts (20.16) were 
examined very effective. [15] evaluated three different plant leaf extracts against red pumpkin beetle Neem, Parthenium spp, Eucalyptus and one chemical check, out of which chemical check and Parthenium were examined very effective.[16] resulted that Neem oil has better result than other botanicals against red pumpkin beetle and chemical treated plants were maximum mortality of red pumpkin beetle[17, 18]. Toxicity response of $M$. azedarach leaf extract demonstrated in present study against red pumpkin beetle adults were highly in consistent with the interpretations of various researchers who documented pesticidal activities of $M$. azedarach extracts against arthropod pests. Present studies can be compared to the studies of [19] tested three different concentrations $(2.0,1.0$ and $0.5 \%)$ of carbaryl for the management of red pumpkin beetle and effect of insecticide was checked after three, five and seven days of application.[20] checked out the effect of carbaryl @ 0.2\%, monocrotophos @ 0.54\%, chlorpyriphos @ 0.05\%, nimbecidine (a neem formulation) @ 0.2\%, Bacillus thuringiensis @ $0.20 \%$, thiodicarb @ 0.075\%,Bt@0.1\% + thiodicarb@0.0375\%, nimbecidine + thiodicarb, spinosad at $0.015 \%$ for the management of red pumpkin beelte. Carbaryl (46.53\% a.i.) was the most effective control measure in reducing the population and infestation of red pumpkin beetle. [21] checked out the effect of six treatments including, soil application + Furadan 5G@5 g/plant @ 3 days before planting, mechanical control + sweeping net ( 3 days interval for 45 days, spraying neem seed oil @10m1/1+5m1 trix (detergent) at 7 days interval, spraying neem seed kernel extract@ @ $50 \mathrm{~g} / 1$ of water at 7 days interval, seedling bed covered with mosquito net barrier up to 45 days old seedlings [22] surveyed red pumpkin beetle management practices and reported that cow dung and fly ash as control was used by $77.50 \%$ of people followed by red chili powder $(50 \%)$. The minimum used material was Kala maati by $25 \%$ by the local growers, [23] studied management of RP beetle using; mixture of carbaryl $110 \%$ Wet able Power in pots before sowing, spray of carbaryl, dusting of ash mixed with kerosine oil and application of Parthenium hysterophorus plant extract, and [24] studied the effect of neem oil, mehagoni oil, bishkatali leaf extract, larvin $75 \mathrm{WP}$ and diazinon 60 and their performance for the management of red pumpkin beetle.

\section{Conclusions}

By the application of Malathion 250 L/acre and Imidachloprid 250L/acre the population and damage of red pumpkin beetle was reduced. Plant products also showed the ability to repel and can reduce the damage the red pumpkin beetle. This study proved that red pumpkin beetle can be managed in field with some botanicals and synthetic insecticides. Even though, synthetic insecticides are well understood for controlling this pest but in this study some botanicals are also evaluated to control it, and they have shown a minimum mortality against red pumpkin beetle but keep them away from damaging the crop at least 1 week because of their repellence instead of synthetic insecticides. And it is also understood that botanicals are biodegradable and environmentally friendly then synthetic insecticides. It is recommended that the Malathion 250 L/acre and Imidacholroprid $250 \mathrm{~L} /$ acre can further be utilized as a tool for insect pest management especially against red pumpkin beetle in better gourd in rapid control. It is also recommended that botanicals have great extant of repellence for long term it may be evaluated for the controlling of red pumpkin beet le in for small stack holders.

\section{Authors' contributions}

Conceived and designed the experiments: I Ahmed, SA Shahwani, MI Jakhro, A Hanan, MA Badini \& K Jamil, Analyzed the Data: S 
Ahmed \& ZA Khetran, Contributed reagents/ Materials/ Analysis tools: N Ahmed \& A Latif, Wrote the paper: S Ahmed \& I Ahmed.

\section{References}

1. Singh NP, Singh DK, Singh YK \& Kumar V (2006). Vegetables Seed Production Technology, 1st Ed International Book Distributing Co. Lucknow. pp 143-145.

2. Tahir M \& Haider MS (2005). First report of Tomato leaf curl New Delhi virus Infecting bitter-gourd in Pakistan Plant Patho 54: 807

3. Singh NP, Singh DK, Singh YK \& Kumar V (2006). Vegetables Seed Production Technology, 1st Ed. International Book Distributing Co. Lucknow. pp 143-145.

4. Alam MZ (1969). Insect pests of vegetables and their control in East Pakistan. The Agricultural information service, 3, RK Mission road, Dhaka. pp 146.

5. Yamaguchi M (1983). World Vegetables Dept. of Vegetable Crop, Univ. of California. pp 415.

6. Rajak DC (2001). Host range and food preference of the red pumpkin beetle, Aulacophora foveicollis (L.) (Chrysomelidae: Coleoptera). Agri Sci Digest 21(3): 179-181.

7. Mandal TS, Biswas \& Laskar N (2012). Impact of biophysical characteristics of bitter gourd Momordica charantia (L.) on the infestation of foliage feeding coleopteran pests.Current Biotica 6(1): 103-106.

8. Rathod ST \& Borad PK (2010). Population dynamics of red pumpkin beetle, Aulacophora foveicollis (L.) on pumpkin. Current Biotica. 3(4):565-569.

9. Khursheed, Sheikh, Desh Raj \& Nisar Ganie A (2013). Population dynamics of red pumpkin beetle on cucumber in midhill Himalayas. J of Appl Horti 15(2): 512.
10. Karim MA (1992). Insect pests of vegetable crops and their management. In: Lopez, K. and E. Libas (Eds.). Vegetable production and Marketing. Proc. National Review and Workshop held at BARI, Gazipur, Bangladesh on January 26-29. 1992. Asian Vegetable Research and Development Center, Shanhua, Tainan, Taiwan. Publication No. 92-379. pp 110-112.

11. Statistix (2006). Analytical Software. Statistix 8.1 User's Manual. Analytical Software, Tallahssee (Florida).

12. Alam MZ (1969). Insect pests of vegetables and their control in East Pakistan. The Agricultural information service, 3, RK Mission road, Dhaka. pp 146.

13. Singh JP \& Gupta R (1970). The red pumpkin beetle Raphidopalpa foveicollis (L.), as a pest of the Japanese mint. $J$ of Bombay Natur Hist Socie 67(1): 123-124.

14. Rathod ST \& Borad PK (2010). Population dynamics of red pumpkin beetle, Aulacophora foveicollis (L.) on pumpkin. Current Biotica 3(4): 565-569.

15. Ali H (2011). Efficacy of different botanicals against red pumpkin beetle (Aulacophora foveicollis (L.) in bitter gourd Momordica charantia (L.).Pakistan J Weed Sci Res 17(1): 6571.

16. Osman S, Uddin MM \& Adnan SM (2013). Assessment of the performance of different botanicals and chemical insecticides in controlling red pumpkin beetle Aulacophora foveicollis (L). Intern J of Agri Sci and Res 2(1): 258264

17. Italo CG, Amanda HF \& Diego LR (2009). Physical and chemical characterization of Melia azedarach (L.) fruit and leaf for use as botanical insecticide. Chilean J of Agri Res 69(2): $38-45$. 
18. Kumral NA, Cobanoglu S \& Yalcin C (2010). Acaricidal, repellent and oviposition deterrent activities of Datura stramonium (L.) against adult Tetranychus urticae (Koch). J of Pest Sci 83(1): 173-180.

19. Khan SM\& Jehangir M (2000). Efficacy of different concentrations on sevin dust against red pumpkin beetle Aulacophora foveicollis (L.) cause damage to the Muskmelon Cucumis melo (L.) crop. Pakistan J biol Sci 3(2):183-185.

20. Lakshmi MV, Rao GR \&Rao PA (2005). Efficacy of different insecticides against red pumpkin beetle, Raphidopalpa foveicollis (L.) on pumpkin, Cucurbita maxima (D.). J of Appl Zool Res 16(2): 73-74.

21. Khorsheduzzaman AKM, Nessa Z \& Rahman MA (2010). Evaluation of mosquito net barrier on cucurbit seedling with other chemical, mechanical and botanical approaches for suppression of red pumpkin beetle damage in cucurbit. BanglaJ Agric Res 35(4): 395-401.

22. Nath D \& Ray DC (2012). Traditional management of red pumpkin beetle, Raphidopalpa foveicollis (L.) in Cachar district, Assam. Ind Trad Know 11(2): 346- 350.

23. Bharathi LK \& John KJ (2013). Momordica genius in Asia - An overview. Springer India, http://www.springer.com/978-81-3221031-3.

24. Osman S, Uddin MM \&Adnan SM (2013). Assessment of the performance of different botanicals and chemical insecticides in controlling red pumpkin beetle Aulacophora foveicollis (L.). Intern J of Agri Sci and Res 2(3): 258264. 